\title{
Equilibrium Of The Governments By The Principle Of Subsidiary
}

\author{
By Xhabir Zejnuni ${ }^{1}$
}

\begin{abstract}
.
The principle of subsidiarity on these days is not identified so much as a legal or philosophical concept, but as testing capabilities and possibilities of this principle. Application of the principle of subsidiarity is able to exploit the potential of all collectivity, fully implementing the Constitution. The task of the juridical order must be recognition of the dignity of every person; which should be promoted and evaluated through a legislation based on the principle of subsidiarity. This principle expresses a preference in performing the functions of government at the closest level of citizens. Subsidiarity can be of various types such as horizontal or vertical; positive or negative; static or dynamic; substantive or procedural. In some countries, subsidiarity is specifically defined in their constitutions, while in some other countries is implied. But this principle in the civil law is defined more directly. Subsidiarity does not find the same application in all states and this fact depends not only on each country's traditions but also and in their development.
\end{abstract}

Key words: Subsidiarity, Constitution, State, juridical order, low.

\section{Introduction}

Subsidiarity has gained great importance in today's times, becoming a keyword in the European policy debate and the promotion and his involvement in the treaties of international law. Today in the field of public law is very difficult to found a work where is not mentioned this principle, which solves the problems of the separation of powers between the different entities, which allow the combined action of these subjects in solving common problems and that is not based only on domination, control and intervention. Subsidiarity also allows subjects qualified and prepared to exercise powers that are the most suitable for them. It should be emphasized that the importance of a legal principle can be seen more clearly from its current implementation and not by his declaration or definition. The principle of subsidiarity serves to reorganize the division of powers, which can be achieved only when it is possible to know who is the most convenient and most effective of these powers. In order to function effectively subsidiarity, should be provided not only by law, but should also be based on a real autonomy of institutions capable of exercising the powers that are given to them by the law. The principle of subsidiarity is in the preference for placing government functions at the level closest to the people, where the state and social groups interfere according to 
the principle of fulfilling the functions. Subsidiarity may affect the relationship between institutions, but also their relations and society, since the State cannot interfere, except to the extent that lower authority and closer to individuals shows his inability. It should be emphasized that the principle of proportionality finds here its immediate implementation, as the intervention would be legitimate only to the extent that it would be necessary. The practical application of the subsidiarity is principle can be useful especially in economic terms, as an institution is worth more to help its members to practice their skills than to remove them the opportunity and to exercise itself later. Subsidiarity is the regulator principle, where if a subject that is "below" is able to do something good, then the entity that is "above", must enable this task, but also to support if necessary.

But the main principle of subsidiary is one which the "Exercising of public responsibilities should, in general, belong more to the authorities closest to the citizens. Granting of a responsibility to another authority should be done by considering the nature of the task, as well as the capability requirements of the economy ".

At Lexicon Totius Latinitatis 2 is found the definition of subsidiary as " $A$ boon beld in reserve and provided if needed, when those who have the obligation to fulfill a task are not able to accomplish it"

Subsidiary has two meanings:

1. the one that relates to the idea of replacing and

2. the other one related to the idea of assistance and means an intervention.

\section{Contribution of the Catholic Church on subsidiarity.}

Subsidiarity is handled by Christian-Democrat current, who introduced it to his political-ideological heritage, while originally conceived in the vertical direction, so as democratic and efficient distribution of powers between different levels where power is exercised and subsequently in horizontal direction as an effort for the separation of powers between civil and the individual society.

Its position in relation to the subsidiary, the Catholic Church has expressed through several encyclical ${ }^{3}$.

The first document, which is expressed about subsidiary, is Encyclical Letter Rerum Novarum 4 is by Pope Leo XIII, who at paragraph 28 says: "It is not fair that the resident and

\footnotetext{
${ }^{1}$ European Charter of Local Autonomy

Article 4 item 3

${ }^{2}$ Latinitatis Totius Lexikon is a work of the Padovan priest Egidio Forcellini (1705-1768) that was completed in 1761 and was published after his death in 1771. This act is still regarded today as an essential tool for all those who are devoted to reading and translation of the Latin texts.

${ }^{3}$ Encyclopedia is a letter by which Pope makes known the position of the Catholic Church on some specific topics: doctrinal, moral and social.
} 
the family to be absorbed by the State, instead should be entrusted to one or another leeway as far as possible without jeopardizing the common good. [...] If the society or a portion of it is caused a damage that cannot be repaired in any way, then it is necessary the intervention of the State".

A clearer formulation of the principle of subsidiary appears to encyclical Quadragesimo Anno ${ }^{5}$ of Pope PIOs XI stating that: "As it is wrong to remove to the individuals what they can achieve based on their forces and the industry for the community, it is also unfair to leave to a higher society what lower societies can do [...] because any natural object of any intervention of the society is to provide assistance (subsidium) members of the social body, and not to destroy or to absorb them". Further, the encyclical continues that: "It is necessary that the supreme authority of the State leave in the hands of the lower assemblies the issues and concerns of lesser importance in order to be able to perform more freely, more powerfully and effectively the parts that belong to [...] of the management, supervision, oppression, depending on the circumstances and needs".

In his encyclical Pacem in Terris, ${ }^{6}$ Pope John XXIII in relation to the implementation of subsidiarity in the international field states: "As the relationships between individuals, intermediate groups and public authorities within their respective political communities should be regulated under the principle of subsidiary, so in light of the same principle should be regulated the relations between public authorities and public powers of World Community".

While Benedict XVI in the encyclical Deus Caritas est ${ }^{7}$ explains how government should be organized to the groups of State noting that: "There is not a State which regulates and controls everything that we need, but a State which accepts and generously supports in accordance with the principle of subsidiarity initiatives arising from the different social forces, combining spontaneity and closeness to those in need".

The subsidiary originally by the Catholic Church has been emphasized the positive aspect and the negative aspect later.

So while in the encyclical Rerum Novarum, Pope Leo XIII had affirmed the need for State's intervention to combat the excesses produced by liberalism, in the encyclical Quadragesimo Anno, Pope Pius XI stressed the principle of non-interference by the State.

\section{Subsidiarity in European Community law.}

Subsidiarity is clearly mentioned for the first time in the report of the European Commission dated 26/06/1975 on the European Union, which had proposed 'In

\footnotetext{
${ }^{4}$ Rerum Novarum " (new issues) is the title of the social encyclical promulgated on May 15, 1891 by Pope Leo XIII, by means of which for the first time the Catholic Church took a clear position in relation to social problems and founded the Christian social doctrine.

5 'Quadragesimo Anno (the fortieth year) is the title of Social Encyclical promulgated on May 15, 1931 by Pope Pius XI, who affirmed the value of the social doctrine of the Catholic Church.

6 " Pacem in Terris" (peace on earth) is the latest encyclical of Pope John XXIII on 11 April 1963, before he passed away two months later.

7 'Deus Caritas Est " (God is Love) is Encyclopedic First Letter of Pope Benedict XVI, which was signed on 25.01.2005 and was published on 01/25/2006.
} 
accordance with the principle of subsidiarity", delegation of the European Union only to those tasks that member states are not able to meet satisfactorily. Later, this principle was introduced in "McDougal Report" of 1977, in connection with fiscal federalism and Constitutional -Treaty, adopted by the European Parliament in 1984, which outlined a completed federal system. But it is only the Single European Act that the principle of subsidiarity emerges in environmental policy, in research and technological development and in economic and social cohesion. It is noteworthy that community intervention is not the same in these areas, as it is more intense in the environmental field and less in the other two fields. Subsidiarity has found further expansion in the Treaty of Maastricht ${ }^{8}$, where it is qualified as a fundamental principle of the European Union, referring to the preamble of the Treaty: "[...] Determined to push forward the process of establishing a closer union between the nations of Europe, where decisions are taken closer to citizens in accordance with the principle of subsidiarity". To properly implement subsidiarity, it is necessary to create clearly (as in Article 5 (3B) of the European Community Treaty) exercise of the powers and responsibilities in relation to this principle, where the subsidiarity is a guiding principle of relations between the European Union and its member states, as: "the Community shall act within the limits of the powers and set objectives for it by this Treaty. In areas which do not take part within its exclusive competence, the Community intervenes in accordance with the principle of subsidiarity, only, and while the objectives of the proposed action cannot be sufficiently achieved by the member states and that the reason of the scale or effects of the proposed action, are better achieved at the Community level. Community action should not go beyond what is necessary to achieve the objectives of this Treaty". Thus, subsidiarity community means exercising the powers of the European Community, except in cases where such an exercise belongs to the Member States. Section A9, par. 2, provides that "This Treaty marks a new stage in the process of creating an ever closer union between the nations of Europe, where decisions are made in the most transparent manner possible and closer to the citizen". Subsidiarity principle objects are proper exercise of powers, measures and forms of community action in the field of joint organ powers recognized by the Treaty. Subsidiarity is very necessary to maintain the federal balance in the European Community and should not be understood as the limitation of immediate and direct application rules of the Treaty or as a distribution of competences between the European Community and its Member States.

This principle governs the exercise of powers in competitive issues and in particular allows determining the most appropriate level to regulate a particular sector based on the parameters set out in Protocol 2, which asks EU institutions to legitimize their actions and show more effectiveness than what could be achieved at the national level.

\section{Types of subsidiarity.}

Horizontal and vertical subsidiarity.

Horizontal subsidiarity has its distinctive criterion the separation of administrative functions between public on one hand and private on the other, thus affecting the

\footnotetext{
8 Signed on 07.02.1992.

9 Today Article I of Treaty of the B.E.
} 
relationship between society and its components, according to the principle that "society itself cannot replace individuals in what they can make in their own or in cooperation with each other". Horizontal subsidiarity regulates the relations between the State, social groups and individuals, where individuals alone or through intermediate bodies, should be able to collaborate with institutions in determining interventions that affect their social reality, where these needs are met by the individuals as partnership or voluntary.

Vertical subsidiarity has its own distinctive criterion the separation of administrative functions among different levels of government and generally governs the relationship between the State and higher societies on one hand, and low societies on the other hand, where the previous cannot perform the functions that the latest are able to do themselves and adequately, as the high societies and State cannot replace the lower societies in performing their tasks, which they are able to do independently. Vertical subsidiarity applies not only to relations between public authorities within the same legal system as a Municipality, County and State, but also relates to the relationship between the European Community and its Member States. Vertical Subsidiarity places distribution of powers between the State and local authorities, where hierarchical separation of powers should be moved to institutions closer to the citizens, where their needs are met by the action of public administrative authorities.

\section{Positive and negative subsidiarity.}

Positive subsidiarity gives each entity the duty to promote, support and replace inefficient individuals in accordance with the obligation to intervene. This principle is not hesitant about the role and importance of the State but strive to enhance and assess the dynamics of the relationship between the State and citizens, and between the public and private. On the positive aspect, the State and other public entities that constitute it should provide financial, institutional and legislative support the interested small entities as associations, family, church etc. The state authorizes the intervention when individuals and small companies are not able to perform certain functions and provide the benefits they need for themselves autonomously. Thus, positive subsidiarity is not only a ban on higher entities that interfere instead of the lowest levels entities in certain areas, but also an obligation to intervene when subordinate entities are not able to perform certain tasks.

To negative subsidiarity, the State should refrain from intervening in certain areas, in order not to hinder the entities that can fulfill a specific need better than the State itself, struggling not the inefficiency, unnecessary spending and an excessive bureaucratic centralization. Not intervention stems from the conviction that the State in particular, but also every power that flows from it, should not prevent individuals and social groups to be free to act, to use their energy and perseverance in achieving the full realization of themselves, in the best of the general and particular interest. In this case, individuals and society are guaranteed freedom of action in various sectors by the State, which in turn should not interfere in these areas. 


\section{Subsidiarity in federal countries.}

Among countries that include in their legislation the principle of vertical subsidiarity, are distinguished first of all federal countries like the United States of America, Germany and Switzerland.

The Card of Rights of the United States, ratified on 15th December 1791, includes the principle of subsidiarity in Amendment X, which states that "powers not delegated to the federal government Constitution, or are not probibited by the United State, are reserved to the relevant States, or people”. From the wording of this amendment, it is meant the vertical nature of subsidiarity in the US Constitution.

Article 30 of the German Basic Law ${ }^{10}$ states that "The exercise of public powers and performance of duties arising from the State, belonging to the Länder, to the extent that the underlying law does not provide for or accept another regulation". From this, it follows that all powers belong to the Länder, but otherwise the powers of the Federation shall be legitimized and it can only intervene in the event of failure of the local authorities. In other words, the Federation possesses only certain functions in cases of necessity. German Federalism is thus a model which is based on the principle of subsidiarity, comprising a tool that on one hand promotes competition among individual countries in order to create better living conditions for citizens and in turn leads to action the State in a vertical direction, thus closer to the citizen.

Swiss Federal Constitution, being inspired by the Constitution of the United States of America and the ideas of the French Revolution, from its inception on September 12 th, 1848, lays down in particular in Article 3 the principle of subsidiarity, according to which "The cantons are sovereign insofar as their sovereignty is not expressly limited by the Federal Constitution ". Even in this case it comes to vertical Subsidiarity.

\section{Subsidiarity in Albania.}

In Albania, the principle of subsidiarity is not explicitly ${ }^{11}$ mentioned in its Constitution $^{12}$, but only implied.

Expressively subsidiary is mentioned in the ordinary laws such as the Law no. 10119 dated 23.04.2009, "On Territorial Planning". which in Article 4, entitled "Principles of territorial planning" states that: "The law is intended to ensure compliance with the norms, standards and legislation in the field of construction, urban planning and water resources in the whole country, decentralized and in accordance with the principle of subsidiarity, according to the administrative division". Subsidiarity is better specified in Article 1, entitled "The purpose", which states that: "The exercise of public responsibilities should, in general, belong more to the authorities closest to the citizens. Allocation of responsibilities to another

${ }^{10}$ Constitution of Germany called the Basic Law, which was approved on May 23, 1949.

${ }^{11}$ Explicit

12 Albania's Constitution

Article 11, 13, 15, 59, 112, 113, 157. 
authority should be done by taking in consideration the nature of the task, as well as the requirements of capabilities and the economy".

Regarding the subsidiarity, Albania's Constitutional Court issued a decision and states that if one side "Powers, with which the law assures local government bodies should be such that a good portion of public issues are regulated by the principle of subsidiarity" and if "the legal right which regulate and manage certain public issues should be exercised by organs that are closer to citizens and be accompanied by effective means for their materialization", on the other hand should be claimed that "In reality many issues have implications both local and national and the responsibility for them varies in space and time, and moreover, this responsibility can be shared between different levels of government".

\section{Conclusion.}

As stated above, is noted that subsidiarity is a very important element not only in the alignment but also in the independence of the operation in terms of power both in the vertical and horizontal aspect. But is noted that subsidiarity in constitutional viewpoint is not getting adequate protection in most states, because this principle is not explicitly mentioned, but more implied. It should be emphasized that subsidiarity finds more constitutional protection in federal states in which is given very importance the social aspect of this principle. While in the common civil or administrative low the principle of subsidiarity is mentioned explicitly and finds a suitable protection. But, in the realization of these principles are also noted some anomalies, as in the relationship between central and local government, can be seen a fruitful cooperation when these powers coincide politically, (ie when the leaders of these powers belong to the same political branch) and on the other hand there is a kind of "freeze cooperation" when powers are not matched politically. This anomaly stems from the democratic political culture, which is not at the expected levels and desired by the only beneficiaries of subsidiarity such as specific and the collectivity individuals.

\section{References.}

Egidio Forcellini "Lexicon Totius Latinitatis", 1771.

Encyclical Quadragesimo Anno, 1931.

Encyclical Pacem in Terris, 1963.

Encyclical "Deus caritas est" 2006.

European Charter of Local Autonomy.

The USA's Constitution.

The Swiss' Constitution.

Albanian's Constitution.

Germany's Basic Law.

Law no. 10119 dated 23.04.2009, "On Territorial Planning.

EU Treaty. 
